\title{
CLINICAL CHARACTERISTICS OF PATIENTS WITH INTRADIALYTIC HYPERTENSION
}

\section{Natasa Eftimovska-Otovic ${ }^{1}$, Risto Grozdanovski ${ }^{1}$, Borjanka Taneva ${ }^{2}$, Olivera Stojceva-Taneva ${ }^{3}$}

${ }^{1}$ Specialized Hospital for Nephrology and Dialysis Diamed Skopje, R. Macedonia

${ }^{2}$ University Clinic for Cardiology, Medical Faculty, Skopje, R. Macedonia

${ }^{3}$ University Clinic for Nephrology, Medical Faculty, Skopje, R. Macedonia

Corresponding Author: Dr.mr.sci. Natasa Eftimovska-Otovic, Specialized Hospital for Nephrology and Dialysis Diamed Skopje, R. Macedonia

\begin{abstract}
Introduction: Intradialytic hypertension with a prevalence of $15 \%$ among hemodialysis patients is with unknown pathophysiology, demographic, laboratory and clinical characteristic of patients, and it's influence on longterm clinical effects (cardiovascular morbidity and mortality, rate of hospitalization). The aim of the study is to present the clinical, laboratory and demographic characteristics of patients with intradialytic hypertension in our dialysis center.

Materials and methods: Out of 110 hemodialysis patients, 17 patients $(15,45 \%)$ had intradialytic hypertension - started at a systolic pressure greater than $140 \mathrm{~mm} \mathrm{Hg}$ or had an increase in systolic pressure more than $10 \mathrm{~mm} \mathrm{Hg}$ during the session, and 17 patients were normotensive or had a drop in blood pressure during the dialysis. HD were performed 3 times per week with a duration of 4-5 hours, on machines with controlled ultrafiltration and high flux syntetic membrane (polyetersulfon) sterilized with gamma rays. A dialysate with standard electrolytes content was used $\left(\mathrm{Na}^{+} 138\right.$ $\mathrm{mmol} / \mathrm{L}, \mathrm{K}^{+}$2,0 mmol/L, $\mathrm{Ca}^{++} 1,5 \mathrm{mmol} / \mathrm{L}, \mathrm{Mg}^{+} 1,0 \mathrm{mmol} / \mathrm{L}, \mathrm{CH}_{3} \mathrm{COO}^{-} 3,0 \mathrm{mmol} / \mathrm{L}, \mathrm{Cl}^{-1} 110 \mathrm{mmol} / \mathrm{l}$, $\mathrm{HCO}_{3}-35 \mathrm{mmol} / \mathrm{L}$ ). We analysed the following demographic and clinical characteristics: gender, age, BMI, dialysis vintage, vascular acces, cardiovascular comorbidity (cardiomyopathy, ischemic cardiac disease, peripheral artery disease, heart valve disease), number and type of antihypertensive drugs, weekly dose of erythropoesis - stimulating agent, standard monthly, three and six months laboratory analyzes, and sp Kt/V and PCR. Statistical analysis was performed using the statistical software SPSS 17.0.

Results: In both groups men were predominant (IDH group $88.23 \%$, control group $64.07 \%$ ). The IDH group was older $(59.00 \pm 7.64$ versus $49.00 \pm 13.91, \mathrm{p}=0.314)$ and with lower BMI $(\mathrm{p}=0.246)$ compared to the control group. The IDH patients had significantly lower serum sodium and higher sodium gradient $(135.75 \pm 2.03$ versus $137.33 \pm 1.97, \mathrm{p}=0.042 ; 2.25 \pm 1.98$ versus $0.66 \pm 1.44, \mathrm{p}=$ 0.0267 , respestively). All other laboratory findings showed no statistically significant differences between the two groups. The IDH group had significantly higher interdialysis weight gain and less effective ultrafiltration individually at each dialysis session compared to the control group $(2.23 \pm$ 0.866 versus $2.37 \pm 0.69, p=0.011 ; 3.87 \pm 1,26$ versus $3.56 \pm 1.18, p=0.025$, respectively). The systolic and mean arterial pressure after the HD were statistically higher in the IDH group.

Conclusion: Older age, lower BMI, borderline hyponatremia, higher sodium gradient and smaller ultrafiltration rate are the clinical characteristics of patients with intradialytic hypertension.
\end{abstract}

Key words: hypertension, hemodialysis, characteristics.

Introduction

Intradialytic hypertension, defined as an increase in systolic pressure more than $10 \mathrm{~mm}$
$\mathrm{Hg}$ during hemodialysis (HD) is a relatively common problem that affects more than $15 \%$ of hemodialysis patients [1]. Although the prob- 
lem has been known for decades, the pathogenetic mechanism is not yet clarified. Most authors agree that intradialytic hypertension is multifactorial: volume overload, increased activity of the sympathetic nervous system and the renin - angiotensin - aldosterone axis (RAAS), imbalance of electrolytes, particularly sodium and calcium, endothelial dysfunction, removal of antihypertensive drugs in dialysis [2]. Apart from the unknown etiopatogenesis of the intradialytic hypertension, little is known, also, about the demographic, clinical and laboratory characteristics of patients, and its impact upon long-term clinical complications (cardiovascular morbidity and mortality, hospitalization rate). Patients with intradialytic hypertension, who were followed by USRDS Wave II study, have shown less interdialytic weight gain, had smaller "dry" weight, took a greater number of antihypertensive medications and had lower values of serum albumin compared to patients who did not have an increase of the intradialytic blood pressure [3]. Another study reported that intradialytic hypertensive patients were older and had lower value of serum creatinine [4].

The aim of this study is to present the clinical, laboratory and demographic characteristics of patients with intradialytic hypertension in our hemodialysis center.

\section{Methods and materials}

From a total of 110 hemodialysis patients, 17 patients $(15.45 \%)$ met the inclusion criteria in the study (intradialytic hypertensive group - IDH group) and 17 normotensive patients were randomly selected as controls. So, the study included 34 patients, followed within a period of four consecutive weeks (i.e. 12 hemodialysis sessions) having blood pressure monitored before, during and after the hemodialysis session. Criteria for intradialytic hypertension were: systolic blood pressure greater than $140 \mathrm{~mm} \mathrm{Hg}$ prior to HD or a rise in systolic pressure more than $10 \mathrm{~mm} \mathrm{Hg}$ during the session, and patients without intradialytic hypertension were those who remained normotensive or had a decline in blood pressure during HD. Hemodialyses were performed three times a week with a duration of 4 to 5 hours per session, on machines with controlled ultrafiltration and HD filters with synthetic membrane (polyetersulfon) high flux, sterilized by gamma rays. Dialysate solution with standard electrolyte composition $(\mathrm{Na}+138 \mathrm{mmol} / \mathrm{L}, \mathrm{K}+2.0$ $\mathrm{mmol} / \mathrm{L}, \mathrm{Ca}++1.5 \mathrm{mmol} / \mathrm{L}, \mathrm{Mg}+1,0 \mathrm{mmol} / \mathrm{L}$, CH3COO-3.0 mmol/L, Cl -110 mmol/l, HCO3$35 \mathrm{mmol} / \mathrm{L}$ ) was used. The dialysate sodium concentrations were identical for all the patients and were set up to $138 \mathrm{mmol} / \mathrm{L}$. The blood flow rates ranged between 280 to $300 \mathrm{ml} / \mathrm{min}$, and the dialysate flow from 500 to $600 \mathrm{ml} / \mathrm{min}$. The rate of ultrafiltration was determined individually depending on the accumulated fluid in the interdialytic period and the need to achieve the dry weight of the patient. For every patient in each dialysis session the weight was measured before, after and prior to the next HD. The blood pressure and heart rate were measured before the start and after the session in a sitting position with legs drawn down after 5 minutes of rest, and hourly during the dialysis. The total effective ultrafiltration was calculated from the difference of the pre - dialysis and post - dialysis weight of the patient, the interdialytic fluid accumulation was derived from the difference in weight before the next HD and the current weight after the HD. The sodium gradient was calculated from the difference between the dialysate sodium (138 mmol/L for all patients) and the measured plasma sodium before the start of the HD. The Mean blood pressure was calculated as the sum of the systolic plus doubled diastolic pressure and divided by three. Demographic and clinical characteristics of interest were: gender, age, BMI (body mass index), dialysis vintage, vascular access, cardiovascular comorbidities (cardiomyopathy, coronary artery heart disease, peripheral arterial disease, disease of the heart valves), number and type of antihypertensive drugs, weekly dose of erythropoietin stimulating agent. The biochemical analyses performed monthly were: hematocrit, hemoglobin, urea, creatinine, sodium, potassium, calcium, ionized calcium, phosphorus, iron saturation, sp $\mathrm{Kt} / \mathrm{V}$ (single pool $\mathrm{Kt} / \mathrm{V}$ ). Each three months the serum albumin, CRP (C-reactive protein), ferritin, PCR (protein catabolic rate) were assessed, and every 6 months the parathyroid hormone was measured. Laboratory data were analyzed for the period from 1.09.2012 to 1.05.2013. 
The statistical analysis was performed using the statistical software SPSS Statistics $17^{\text {th }}$. The results were expressed as mean $( \pm$ SD) and confidence interval (CI). Student $\mathrm{t}$ - test was used to analyze differences in numerical data between measurements in both investigated groups, and chi square test and Fisher exact $p$ test was used for nominal data. The $\mathrm{p}$ value of less than 0.05 was taken to be statistically significant.

\section{Results}

Table 1 shows the demographic and clinical characteristics of both patient gropus. $\mathrm{Ba}-$ sed on the demographic characteristics in the two groups, men were more frequent $(88.23 \%$ in the IDH group, $64.70 \%$ in the control group). Regarding age, the IDH group was older, but there was no statistically significant difference compared to the control group $(59.00 \pm 7.64$ versus $49.00 \pm 13.91,95 \% \mathrm{CI}-$ $4.39-1286, \mathrm{p}=0,314)$. The BMI in the IDH group was lower compared to the control group, but it did not appear to be statistically significant.

Table 1

Demographic and clinical characteristics of patients with intradialytic hypertension (IDH group) and the control group $(p=0,05)$

\begin{tabular}{|c|c|c|c|c|c|}
\hline \multirow{2}{*}{ Variables } & & IDH group & Control group & $\begin{array}{c}\text { Chi-square } \\
\text { test }\end{array}$ & $\begin{array}{c}\text { Fisher exact p } \\
\text { (one tailed) }\end{array}$ \\
\hline \multirow{2}{*}{ Gender } & Men & $15(88.23 \%)$ & $11(64.70 \%)$ & & \\
& Women & $2(11.76 \%)$ & $6(35.29 \%)$ & 2.62 & 0.1123 \\
\hline \multirow{2}{*}{ Vascular accses } & Catheter & $1(5.88 \%)$ & $1(5.88)$ & & 0.7576 \\
\cline { 2 - 6 } & AVF & $16(94.11)$ & $16(94.11)$ & 0.00 & $\begin{array}{c}\text { Student t-test } \\
\text { p value }\end{array}$ \\
\hline & & & & $\mathbf{9 5 \%}$ CI & 0.314 \\
\hline Age & & $\mathbf{5 9 . 0 0 \pm 7 . 6 4}$ & $49.00 \pm 13.91$ & $-4.39-12.86$ & 0.246 \\
\hline BMI & & $\mathbf{2 3 . 1 2} \pm \mathbf{3 . 2 2}$ & $25.96 \pm 5.06$ & $-3.969--1.091$ & 0.491 \\
\hline $\begin{array}{c}\text { Dialysis vinatge } \\
\text { (months) }\end{array}$ & & $\begin{array}{c}36 \pm 67.51 \\
(12-244 \text { months })\end{array}$ & $\begin{array}{c}36 \pm 108.35 \\
(12-420 \text { months) }\end{array}$ & $-47.75-95.28$ & 0 \\
\hline
\end{tabular}

Regarding the laboratory data, the intradialytic hipertensive patients had statistically significant lower serum sodium compared to the control group $(135.75 \pm 2,03$ versus 137.33 $\pm 1.97,95 \%$ CI $-2.635-0.0582, \mathrm{p}=0,042)$ and consequently greater sodium gradient $(2,25 \pm$ 1,98 versus $0.66 \pm 1.44,95 \%$ CI -0.537 $1.761, p=0.0267)$. In terms of other analyzed parameters, there was no statistically significant difference between the two groups. (Table 2).

Table 2

Comparison of laboratory data between both study groups

\begin{tabular}{|c|c|c|c|c|}
\hline Parameters & IDH group & Control group & 95\% CI & p value \\
\hline Hct & $36.68 \pm 5.18$ & $37.48 \pm 2.80$ & $-2.56-2.43$ & 0.955 \\
\hline Hemoglobin & $118.25 \pm 16.04$ & $118.50 \pm 8.02$ & $-9.65-9.00$ & 0.942 \\
\hline Creatinin & $784.75 \pm 153.75$ & $776.25 \pm 198.90$ & $-122.12-141.12$ & 0.880 \\
\hline Urea & $20.26 \pm 3.81$ & $20.16 \pm 2.51$ & $-1.858-2.466$ & 0.770 \\
\hline Sodium & $\mathbf{1 3 5 . 7 5} \pm \mathbf{2 . 0 3}$ & $137.33 \pm 1.97$ & $-2.635-0.0582$ & $\mathbf{0 . 0 4 2} *$ \\
\hline Potasium & $5.38 \pm 0.671$ & $4.91 \pm 0.489$ & $-0.160-0.693$ & 0.205 \\
\hline Calcium & $2.20 \pm 0.113$ & $2.26 \pm 0.107$ & $-0.147-0.010$ & 0.086 \\
\hline Ionized calcium & $1.11 \pm 0.039$ & $1.15 \pm 0.053$ & $-0.060-0.0003$ & 0.052 \\
\hline Phosphorus & $1.475 \pm 0.236$ & $1.56 \pm 0.33$ & $0.363-0.0821$ & 0.20 \\
\hline Serum albumin & $37.93 \pm 3.24$ & $38.00 \pm 2.06$ & $-2.169-1.726$ & 0.813 \\
\hline Feritin & $396.0 \pm 264.25$ & $435.5 \pm 226.56$ & $-208.36-140.00$ & 0.683 \\
\hline
\end{tabular}




\begin{tabular}{|c|c|c|c|c|}
\hline TSAT & $28.06 \pm 7.92$ & $31.74 \pm 7.45$ & $-9.486-2.968$ & 0.284 \\
\hline CRP & $2.92 \pm 4.70$ & $3.84 \pm 6.48$ & $-4.676-4.364$ & 0.943 \\
\hline Sp Kt/V & $1.35 \pm 0.115$ & $1.43 \pm 0.26$ & $-0.22-0.038$ & 0.152 \\
\hline PCR & $0.93 \pm 0.175$ & $0.877 \pm 0.146$ & $-0.093-0.110$ & 0.857 \\
\hline PTH & $210.0 \pm 214.17$ & $280.00 \pm 265.09$ & $-218.74-65.12$ & 0.268 \\
\hline Dry body weight & $70.62 \pm 10.00$ & $64.75 \pm 24.76$ & $-8.33-15.80$ & 0.521 \\
\hline Sodium gradient & $\mathbf{2 . 2 5} \pm \mathbf{1 . 9 8}$ & $0.66 \pm 1.44$ & $-0.537-1.761$ & $\mathbf{0 . 0 2 7 6}^{*}$ \\
\hline
\end{tabular}

There was also a statistically significant difference of the interdialytic weight gain (2.51 \pm 0.81 versus $2.36 \pm 0.71,95 \mathrm{CI}-1.39-0.241, \mathrm{p}$ $=0.011$ ) between the groups and percentage of interdialytic weight gain $(3.87 \pm 1.26$ versus $3.56 \pm 1.18,95 \%$ CI $-2.30-0.207, \mathrm{p}=0.025)$. Statistically significant difference was confir- med in the effective ultrafiltration: patients in the IDH group had smaller effective ultrafiltration individually at each dialysis session, compared to the control group $(2.23 \pm 0.866$ versus $2.37 \pm 0.69,95 \%$ CI $-1.52-0.262, \mathrm{p}=0.011)$. (Table 3).

Table 3

Systolic, diastolic and mean arterial pressure before and after the session and interdialytic weight gain (IDWG), the IDWG\% and size of the effective ultrafiltration between the two groups

\begin{tabular}{|c|c|c|c|c|}
\hline Parameters & IDH group & Control group & 95\% CI & p value \\
\hline Pre-HD systolic pressure & $145,50 \pm 14,13$ & $133,87 \pm 11,65$ & $-0,645-23,62$ & 0,061 \\
\hline Post-HD systolic pressure & $\mathbf{1 5 6 , 8 7} \pm \mathbf{8 , 3 6}$ & $119,00 \pm 12,65$ & $22,05-49,20$ & $\mathbf{0 , 0 0 0} *$ \\
\hline Pre-HD diastolic pressure & $87,37 \pm 9,03$ & $83,50 \pm 7,55$ & $-10,97-8,39$ & 0,766 \\
\hline Post-HD diastolic pressure & $90,12 \pm 7,16$ & $77,37 \pm 11,70$ & $--4,82-23,51$ & 0,167 \\
\hline Pre-HD MAP & $105,58 \pm 6,75$ & $97,29 \pm 29$ & $-5,60-11,53$ & 0,448 \\
\hline Post-HD MAP & $\mathbf{1 1 1 , 0 3} \pm \mathbf{6 , 3 9}$ & $94,08 \pm 9,03$ & $5,66-28,16$ & $\mathbf{0 , 0 0 8} *$ \\
\hline IDWG & $\mathbf{2 , 5 1} \pm \mathbf{0 . 8 1}$ & $2,36 \pm 0,71$ & $-1,39--0,241$ & $\mathbf{0 , 0 1 1} *$ \\
\hline IDWG\% & $\mathbf{3 , 8 7} \pm \mathbf{1 , 2 6}$ & $3,56 \pm 1.18$ & $-2,30--0,207$ & $\mathbf{0 , 0 2 5} *$ \\
\hline UF & $\mathbf{2 , 2 3} \pm \mathbf{0 , 8 6 6}$ & $2,37 \pm 0,69$ & $-1,52--0,262$ & $\mathbf{0 , 0 1 1} *$ \\
\hline
\end{tabular}

The analysis of the blood pressure confirmed statistically significant difference in systolic and mean arterial pressure after hemodialysis, $(156,87 \pm 8,36$ versus $119,00 \pm 12,65, \mathrm{p}=$ 0,$000 ; 111,03 \pm 6,39$ versus $94,08 \pm 9,03$, respectively, $p=0,008)$. All the other measurements of blood pressure were higher in the IDH group compared with the control group (systolic and
MAP before HD session, diastolic before and after HD session), but showed no significant difference. The patients in the IDH group received more antihypertensive medications and had more frequently cardiovascular diseases compared to the patients in the control group, although statistically not significant. (Table 4.)

Table 4

Presence of cardiovascular disease in both groups and antihypertensive therapy

\begin{tabular}{|c|c|c|c|c|}
\hline Parameters & IDH group & Control group & $\begin{array}{c}\text { Chi-square } \\
\text { test }\end{array}$ & $\begin{array}{c}\text { Fisher exact p } \\
\text { (one tailed) }\end{array}$ \\
\hline ACE inhibitors & $3(17.64 \%)$ & $1(5.88 \%)$ & 1.13 & 0.3006 \\
\hline ARB & $2(11.76 \%)$ & $1(5.88 \%)$ & 0.37 & 0.5 \\
\hline Ca- antagonists & $4(23.52 \%)$ & $4(23.52 \%)$ & 0.0 & 0.656 \\
\hline B -blocker & $2(11.76 \%)$ & $3(17.64 \%)$ & 0.23 & 0.5 \\
\hline$\alpha / \beta$ blocker & $2(11.76 \%)$ & $2(11.76 \%)$ & 0.0 & 0.6994 \\
\hline$\alpha$ blocker & $1(5.88 \%)$ & $0(0 \%)$ & 1.03 & 0.5 \\
\hline
\end{tabular}




\begin{tabular}{|c|c|c|c|c|}
\hline Cardiomiopathy & $2(11.76 \%)$ & $1(5.88 \%)$ & 0.37 & 0.5 \\
\hline Ishemic heart disease & $1(5.88 \%)$ & $1(5.88 \%)$ & 0.0 & 0.7576 \\
\hline Heart valve disease & $\mathbf{6}(\mathbf{3 5 . 2 9 \%})$ & 0 & 7.29 & $\mathbf{0 . 0 0 9 2}$ \\
\hline Periferial artery disease & $4(23.52 \%)$ & $1(5.88 \%)$ & 2.1 & 0.1676 \\
\hline
\end{tabular}

\section{Discussion}

Literature data show variable prevalence of intradialytic hypertension, between $10-15 \%$, similar to that shown in our study $(15.45 \%)$ [1, $5]$. The results in our study comfirmed that intradialytic hipertensive patients were older compared to the patients without intradialytic hypertension, although statistically not significant. Other studies have reported that intradialytic hypertensive patients were older and had lower values of serum albumin and creatinine and lower dry weight [3]. That may be explained by the assumption that these patients are more likely to be malnourished and generally drink more liquids. We did not confirm that in our study group, but intradialytic hypertensive patients showed greater dry weight and higher serum creatinine and insignificant differences in serum albumin. This may be due to the fact that our study patients received high flow hemodialysis and had good appetite with sufficient protein and fat intake. The presence of higher weight in intradialytic hypertensive patients compared to the control group may be a result of a higher interdialytic fluid intake and clinically blunt increased extracellular volume. In addition to this assumption is the fact that intradialytic hypertensive patients have statistically significant lower values of serum sodium, and accordingly, larger and statistically significant gradient of sodium compared to the control group, leading to an increase in serum sodium during dialysis (positive sodium balance) which probably stores in the interstitium as osmotic inactive sodium, leading to salt -sensitive hypertension, which is confirmed by other studies $[6,7]$. The positive sodium gradient increases thirst, leading to increased fluid intake and extracellular volume expansion and subsequent development of hypertension [8]. In our study, we confirmed a statistically significant difference in interdialytic weight gain and the percentage of interdialytic weight gain relative to the dry weight in patients with hypertension compared to the control group. This difference is due to the positive sodium gradient in intra- dialytic hypertensive patients, as confirmed in other studies [9], but also in our recently published study where we found a positive correlation between sodium gradient and interdialytic weight gain [10]. Other studies showed that patients with hypertension have intradialysis statistically significant less effective ultrafiltration compared to patients without intradialytic hypertension, which means that the balance of sodium by intermittent dialysis can not be achieved only through convection, but requires ellimination of the interdialysis accumulated sodium by diffusion $[3,4]$.

Several studies have confirmed that the increased serum sodium is a result of the positive sodium gradient, leading to endothelial dysfunction with decreased nitric oxide and PGE2, and increased release of potent endogenous vasoconstrictor - endothelin -1. All that requires a need to run a strict balance of sodium and to individualize dialysate sodium according to the value of the pre-HD serum sodium, which is relatively stable with very small variations of $1-2 \%$. [11].

Our study showed that patients with intradialytic hypertension used more antihypertensive medications and had more frequently cardiovascular diseases compared to the patients without intradialytic hypertension, but it appeared to be statistically not significat, unlike the evidence in other previous studies [12]. Commonly used drugs were ACE-inhibitors and angiotensin- 2 receptor blockers. Previous studies have confirmed that the activation of the RAAS axis is one of the possible mechanisms for the development of the intradialytic hypertension, but other studies have not shown an increase in renin and aldosterone during the HD session in hypertensive patients [12, 13]. However, several authors agree that the use of ACE inhibitors improves endothelial proliferation of progenitor cells, which may explain the improvement of the endothelial function in the intradialytic hypertensive patients receiving large doses of ACE inhibitors [14]. The more common use of antihypertensive drugs in our 
patients may be associated with lack of reaching the dry weight, where a small excess of extracellular volume will result in intradialytic hypertension. The study confirmed a statistically significant higher value of mean arterial pressure and systolic pressure after HD session, which is consistent with the results reported in the world literature. The increase in the mean arterial pressure and systolic pressure during and after hemodialysis is probably associated with the impaired endothelial function and increased secretion of endothelin -1 and increased peripheral resistance, and can occur without significant changes in cardiac stroke volume.

The study has several limitations: small number of participants, no assessment of intradialytic sodium balance, and the blood pressure is not meassured during the interdialytic period by 24-hour ABPM.

\section{Conclusion}

Older age, lower body mass index, borderline hyponatremia, higher sodium gradient and lower ultrafiltration rate are the clinical characteristics of patients with intradialytic hypertension. Predialysis blood pressure values are insignificantly higher in the IDH-group, while postdialysis values (especially systolic and mean arterial pressure) are significantly higher. Nutritional parameters (serum albumin, phosphorus, urea and PCR) were in the reference range and did not significantly differ from the control normotensive group of patients, exept for the lower BMI, but statistically insignificant, too.

\section{REFERENCES}

1. Inrig K.J. Intradialytic hypertension: A less $\mathrm{r}-$ cognized cardiovascular complication of hemodialysis. Am J Kidney Dis. 2010; 55: 580-589.

2. Locatelli F, Cavalli A and Tucci B. The growing problem of intradialytic hypertension. Nat. Rev. Nephrol. 2010; 6: 41-48.
3. Inrig K.J, Patel UD, Toto RD. et al. Association of blood pressure increases during hemodialysis with 2-year mortality in incident hemodialysis patients: a secondary analusis of the Dialysis Morbidity and Mortality Wave 2 Study. Am J Kidney dis. 2009; 54: 881-890.

4. Inrig KJ, et al. Association of intradialytic blood pressure changes with hospitalization and mortality rates in prevalent ESRD patients. Kidney Int. 2007; 71: 454-461.

5. Mees D. Rise in blood pressure during hemodialysis ultrafiltration: a "paradoxical" phenomenon? Int. J. Artif. Organs. 1996; 19: 569-570.

6. Santos F.F.S. and Peixoto J. Aldo. Revisiting the dialysate sodium prescription as a tool for better blood pressure and interdialytic weight gain management in hemodialysis patients. Clin J Am Soc Nephrol. 2008; 3: 522-530

7. Locatell F, Di Filippo S, Manzoni C. Sodium kinetics during dialysis. Semin Dial. 1999; 12 (suppl1): S41-S44.

8. Flanigan MJ. Role of sodium in hemodialysis. Kidney Int. 2000; 76: S72-8.

9. Mendoza JM, Sun S, Chertow MG, et al. Dialysate sodium and sodium gradient in maintenance hemodialysis: a neglected sodium restriction approach?, Nephrol Dial Transplant. 2011; 26(4): 1281-1287.

10. Bogdanoska-Kostadinovska S, EftimovskaOtovic N, Banskolieva - Babalj E, et al. Prescription of individualized dialysate sodium in patients on chronic hemodialysis. MMP. 2013; 66(3): 174-180.

11. Jablonski Kl, Gates PE, Pierce GL. Low dietary sodium intake is associated with enhanced vascular endothelial function in middle aged and older adults with elevated systolic blood pressure. The Adv Cardiovasc Dis. 2009; 3: 347-356.

12. Chou KJ, Lee PT, Chen CL, et al. Physiological changes during hemodialysis in patients with intradialysis hypertension. Kidney Int. 2006; 69: 1833-1838.

13. Bazzato G, Coli U, Landini S, et al. Prevention of intra and postdialytic hypertensive crises by captorpil. Contrib Nephrol. 1984; 41: 292-298.

14. Muller P, Kazakov A, Jagoda P, et al. ACE inhibition promotes upregulation of endothelial progenitor cells and neoangiogenesis in cardiac pressure overload. Cardiovasc Res. 2009; 83: 106-114. 
Резиме

\section{КЛИНИЧКИ КАРАКТЕРИСТИКИ НА ПАЦИЕНТИ СО ИНТРАДИЈАЛИЗНА ХИПЕРТЕНЗИЈА}

\section{Наташа Ефтимовска-Отовиќ ${ }^{1}$, Ристо Гроздановски ${ }^{1}$, Борјанка Танева ${ }^{2}$, Оливера Стојчева-Танева ${ }^{3}$}

\author{
${ }^{1}$ Специјализирана болница за нефрологија и \\ дијализа „Дијамед“ Скопје, Р. Македонија \\ 2 Универзитетска клиника за кардиологија, \\ Медицински факултет, Скопје, Р. Македонија \\ ${ }^{3}$ Универзитетска клиника за нефрологија, \\ Медицински факултет, Скопје, Р. Македонија
}

Boвеg: Интрадијализната хипертензија со преваленција од $15 \%$ меѓу хемодијализните болни с\# уште е со недоволно познатата етиопатогенеза, демографски, лабораториски и клинички карактеристики на пациентите, како и влијанието врз долгорочните клинички последици (кардиоваскуларен морбидитет и морталитет, стапка на хоспитализација). Затоа, цел на оваа студија е да се прикажат клиничките, лабораториските и демографските карактеристики на пациентите со интрадијализна хипертензија во нашиот Центар за хемодијализа.

Ма ееријали и ме тоgи: Од вкупно 110 пациенти со хемодијализа, 17 пациенти $(15,45 \%)$ беа интрадијализно хипертензивни - стартуваа ХД со систоличен притисок поголем од 140 мм Хг или имаа пораст на систоличниот притисок повеќе од 10 мм Хг во текот на сесијата, а 17 беа нормотензивни - останале нормотензивни или имаа пад на крвниот притисок во текот на дијализата. Хемодијализите беа изведувани три пати неделно со траење од 4 до 5 часа по сеанса, на машини со контролирана ултрафилтрација и хемодијализери со синтетска мембрана (полиетерсулфон) со висока проточност, стерилизирани со гама-зраци. Се користеше дијализатен раствор со стандарден електролитен состав $\left(\mathrm{Na}^{+} 138\right.$ $\mathrm{mmol} / \mathrm{L}, \mathrm{K}^{+} 2,0 \mathrm{mmol} / \mathrm{L}, \mathrm{Ca}^{++} 1,5 \mathrm{mmol} / \mathrm{L}, \mathrm{Mg}^{+} 1,0$ $\mathrm{mmol} / \mathrm{L}, \mathrm{CH}_{3} \mathrm{COO}^{-} 3,0 \mathrm{mmol} / \mathrm{L}, \mathrm{Cl}^{-} 110 \mathrm{mmol} / \mathrm{l}$, $\left.\mathrm{HCO}_{3}{ }^{-} 35 \mathrm{mmol} / \mathrm{L}\right)$. Демографски и клинички карактеристики од интерес беа: пол, возраст, ВMI (body mass index), дијализен стаж, васкуларен пристап, кардиоваскуларни коморбидитети (кардиомиопатија, исхемична артериска болест на срцето, периферна артериска болест, болест на срцевите залистоци), број и тип на антихипертензивни лекови, неделна доза на еритропоеза стимулирачки агенс и стандардни месечни, тримесечни и шестмесечни биохемиски анализи, како и sp Kt/V и PCR. Статистичката анализа беше изведена со користење на статистичката програма SPSS Statistics 17.

Резулtа и: Во двете групи повеќе беа мажи (ИДХ-група 88,23\%, контролна група $64,70 \%)$. Во ИДХ-група беа постари $(59,00 \pm$ $7,64$ versus $49.00 \pm 13,91, p=0,314)$ и со помал BMI ( $\mathrm{p}=0,246)$ во однос на контролната група. Сигнификатно понизок серумски натриум и поголем натриум градиент имаа ИДХ-пациентите $(135,75 \pm 2,03$ versus $137,33 \pm 1,97, p=0,042$; $2,25 \pm 1,98$ versus $0,66 \pm 1,44, \mathrm{p}=0,0267$ соодветно). Кај другите лабораториски анализи немаше статистички значајна разлика меѓу двете анализирани групи. ИДХ-групата имаше сигнификатно поголемо интердијализно добивање во тежина и помали ефективни ултрафилтрации поединечно при секоја дијализна сесија, во однос на контролната група $(2,23 \pm 0,866$ versus $2,37 \pm 0,69, \mathrm{p}=0,011 ; 3,87 \pm 1,26$ versus $3,56 \pm$ $1.18, \mathrm{p}=0,025$, соодветно). Систоличниот и средниот артериски притисок по хемодијализа беше статистички повисок кај ИДХ-групата.

Заклучок: Постарата возраст, понизок индекс на телесна маса, гранична хипонатремија, повисок натриум градиент и помала ултрафилтрациона стапка се клиничките особености на пациентите со интрадијализна хипертензија.

Клучни зборови: хипертензија, хемодијализа, карактеристики. 